Onder redactie van:

Prof. mr. dr. B.M.E.M. Schols

Prof. mr. dr. W. Burgerhart

Prof. mr. dr. F.W.J.M. Schols

Mr. F.M.H. Hoens

Mr. G.A. Tuinstra

Mr. J.Th.M. Diks

Mr. M.J.P. Schipper

Mr. dr. N.V.C.E. Bauduin

Mr. E.C.E. Schnackers

Mr. dr. J.W.A. Rheinfeld

\title{
Advotip
}

Erfrecht voor de advocaat

\section{Gevolgen Gratis Grondgebruik: Gift!}

De - allitererende - titel van deze AdvoTip licht reeds een tipje van de (agrarische) sluier op: wat zijn de juridische gevolgen van grondgebruik om niet? Meer bepaald: wat zijn de gevolgen van een dergelijk 'gratis grondgebruik' door een van de erven voor de omvang van de legitieme portie van een onterfde legitimaris?

Medio 2017 kwam deze vraag, als een van de discussiepunten tussen de erven enerzijds en de onterfde legitimaris anderzijds, aan de orde in een procedure voor Hof Amsterdam (ECLI:NL:GHAMS:2017:3075).

Erflaatster, moeder van drie kinderen (twee ervende zoons en een onterfde dochter), was tot haar overlijden op 25 mei 2010 eigenaresse van een perceel grond, meer bepaald een bedrijventerrein met agrarische bestemming, feitelijk gebruikt voor de opslag en stalling van oude metalen, welk feitelijk gebruik op grond van het Besluit Herziening gebruiks- en overgangsbepalingen uit 1989, voor de betreffende gebruiker en diens rechtsopvolgers planologisch gezien gedoogd werd.

Gedurende de periode 1 januari 1994 tot en met de overlijdensdatum van moeder heeft een van beide zoons de grond onafgebroken en om niet in gebruik gehad. Facturen zijn door moeder nooit verzonden, noch is er ooit enige huurvergoeding door haar aan haar zoon in rekening gebracht. De bewindvoerder van de onterfde (en gehandicapte) legitimaris stelt dat hierdoor sprake is van een gift ex artikel 7:186 BW, waardoor de legitimaire massa van artikel 4:65 wordt verhoogd.

De beide zoons ontkennen dat sprake is van een gift. Zij zijn, zo is te lezen in r.o. 3.13, de mening toegedaan dat er, ondanks het feit dat de gebruiker van het bedrijfsterrein een zoon van erflaatster was, geen reden is om deze kwestie anders te benaderen dan als een zakelijke verhouding tussen de eigenaresse van het bedrijventerrein als verhuurster en de betreffende zoon als huurder. Het achterwege laten van het zenden van facturen is volgens hen geen handeling als bedoeld in artikel 7:186 lid 2 BW en valt niet onder het begrip 'gift'. Moeder heeft niets aan haar zoon kwijtgescholden. Pas als dat aan de orde zou zijn, zou er, volgens de beide zoons, sprake zijn van een actieve handeling die een gift zou kunnen opleveren.

Voorts is het, in de beleving van de beide erven, niet gebruikelijk dat een huurder bij voortduring verhuurder moet verzoeken om een factuur aan hem toe te zenden.

Stilzitten kan, aldus de beide zoons, niet leiden tot een gift, die invloed heeft op de omvang van de legitieme portie. Voor het kunnen constateren van een gift is volgens hen een actieve (rechts)handeling, zoals een kwijtschelding, vereist.

Het hof komt, alles afwegende, in r.o. 3.15 tot de volgende slotsom: 
'Vaststaat dat erflaatster [X] daarvoor nimmer huur in rekening heeft gebracht, terwijl $[X]$ het terrein wel beroepsmatig gebruikte en een deel zelfs verhuurde. Onder die omstandigheden is de stelling van [X] c.s. dat het niet zenden van facturen door erflaatster niet als gift kan worden beschouwd onjuist. Ook niet handelen levert een gift op. [X] is verrijkt doordat hij bedrijfsmatig een terrein in gebruik had waarvoor hij geen huur betaalde, terwijl erflaatster is verarmd doordat zij geen rendement over haar bezit ontving. Daarmee is de bevoordeling van [X] door erflaatster uit vrijgevigheid geschied en is sprake van een gift in de zin van artikel 7:186 BW.'

Het moge duidelijk zijn: ook stilzitten kan, in de visie van het hof, een gift opleveren. Deze overweging is mijns inziens van belang voor de praktijk. De advisering in het kader van het opstellen van een testament waarin één of meer kinderen worden onterfd krijgt hiermee een diepere lading. Niet alleen 'zuivere' schenkingen en giften uit het verleden komen in aanmerking, maar ook minder voor de hand liggende situaties, zoals het niet sturen van facturen uit deze casus. Dat maakt een en ander complexer. Een goed beeld van de volledige vermogenspositie van de erflater is altijd van belang bij de advisering omtrent een testament, maar krijgt door deze uitspraak nog meer betekenis. Let $u$ voortaan dus ook op de vier G's (Gevolgen, Gratis, Grondgebruik, Gift) uit te titel van deze AdvoTip.

Overigens lijkt de waarschuwing dat ook niet-handelen casu quo stilzitten een gift kan opleveren in de naderende Sinterklaas- en kerstperiode, ook buiten de sfeer van de legitieme portie op zijn plaats te zijn.

Tot de volgende keer!

mr. dr. J.W.A. Rheinfeld

Vennoot bij FBN Juristen te Amsterdam

Universitair docent agrarisch recht Radboud Universiteit Nijmegen.

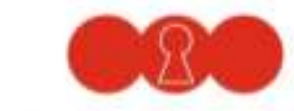

ScholsBurgerhartSchols

www.scholsburgerhartschols.nl

\section{Boomjuridisch}

\author{
Postbus 85576 \\ 2508 CG Den Haag \\ $\mathrm{T}(070) 3307033$ \\ E info@boomjuridisch.nl \\ I www.boomjuridisch.nl
}

